\title{
Removing race: \\ How context and colorblindness influence conceptualizations of equity in a third-grade rural classroom
}

\author{
Jacob S. Bennett, Ph.D. \\ Vanderbilt University, Peabody College
}

\begin{abstract}
The ways teachers both perceive and design supports for her/his/their students are likely influenced by a variety of factors. In this qualitative study, I analyze the ways context and praxis, defined as a teacher's morally informed beliefs about teaching, influenced supports developed for marginalized students in a rural school setting. Over two years of interviews and one year of observations, patterns emerged related to connections between the teacher's beliefs regarding colorblindness, individuality, and the development of instructional and emotional supports for students. I end by discussing recommendations for educational researchers to understand connections between teachers' praxes and practice related to developing equitable supports across classroom contexts.
\end{abstract}

Keywords: Colorblindness; Teaching Praxis; Whiteness; Rural 


\section{Removing race: \\ How context and colorblindness influence conceptualizations of equity in a third-grade rural classroom}

On its most basic level in relation to teaching, the concept of equity pushes teachers to focuses on aspects of an individual student's identity to design supports aimed at ameliorating the effects of historic oppression on student achievement and wellbeing (Milner, 2012). Milner (2010) argued, however, that these effects must be considered in relation to students' racialized identities. Racially-equitable teachers, therefore, seek to understand the ways being seen as a racialized body creates differential experiences both within and between racial groupings based on phenotype, and adapt teaching practices (both relational and instructional) accordingly (Bennett, 2018). Within this conceptualization of equity, praxis can be defined as, "morally informed and committed action" (Edwards-Grovesa, Kemmisa, Hardya \& Ponteb, 2010, p. 43). As such, a teacher's praxis and approach toward racially-equitable instructional practices can be considered intimately connected.

How might a teacher's racial ideology influence the way she/he/they define equity and interact with their students? More specifically, how might certain racial theories such as "colorblindness" influence teachers' practices in the classroom? These questions are important to consider because if equity and acknowledging the effects of being racialized are connected, it could be inherently difficult for teachers who hope to be "colorblind" in their practice to also be equitable. Developing an understanding of how the context of a teacher's classroom (i.e., dynamics between a classroom, school and local community) influences a teacher's perception of the ways they can and should support her/his/their students could be a way to begin answering questions such as these. In an effort to do so, I worked alongside Ruth Austen (pseudonym), a White, heterosexual, Christian, cis-gendered, able-bodied female teacher who adhered to a colorblind racial ideology, to interview and observe her interactions with students (White and minoritized) in her classroom.

Ruth defined colorblindness as, "not taking a person's race into consideration when making judgements about them." She believed such a racial ideology was the most effective way to equitably interact and support students (Interview 4,3/22/2016). I sought to engage Ruth 
in a dialogue about race to understand how she developed her adherence to colorblindness, as well as analyze how the context of her school, Hay Bale Elementary (HBE), influenced her application of colorblindness in relation to supporting students in her class. Before describing our work, I present a review of literature related to the colorblind racial ideology and Whiteness in education to ground our work in the current conceptualizations of each. Doing so can provide a more complete picture of the ways both ideology and Whiteness may have influenced Ruth in her classroom at HBE.

\section{Review of Racial Ideologies}

Ryan, Hunt, Weible, Peterson and Casas (2007) described colorblindness and multiculturalism as possibly the most prominent ideologies related to inter-racial interactions in the United States (US). These authors cited Barrett and George's (2005) explanation of colorblindness becoming the dominant ideology in the US after the Civil Rights Movement of the 1960s. During this time, blatant and violent forms of racism designed by Whites and unleashed on minoritized groups, mainly African Americans, drew the attention of numerous social organizations. Ryan et al., (2007) explained colorblindness was developed as a way to mitigate these negative practices. Individuals who adhere to a colorblind ideology believe harmony between racial and ethnic groups can be found if such distinctions are ignored and all people are treated as "equals." Colorblindness, however, has its critics. It has been argued that ignoring ethnic and racial differences dishonors racialized experiences (Milner \& Laughter, 2015), overshadows the existence of racism in contemporary society (Bonilla-Silva, 2007), and can be used to justify inaction toward racial discrimination in the US (Rosenthal \& Levy, 2010).

Studies conducted in the field of experimental social psychology have substantiated critiques of colorblindness. Apfelbaum, Paukner, Sommers and Ambady (2010) completed a study with sixty students 8-10 years of age. Students were given colorblind or multicultural scenarios (i.e., scenarios that ignored or highlighted the races of individuals within them), and then were asked to identify bias when it blatantly occurred in prompts describing bullying between students. Participants given colorblind scenarios were less likely to identify bias when it blatantly occurred. Such a result was said to have practical implications for teachers. The researchers described a scenario where teachers who were given colorblind prompts described racial bullying on the playground as, "nothing more than ordinary misconduct," and, "unworthy 
of intervention" (Apfelbaum et al., 2010, p. 1591). This substantiates critiques like those of Bonilla-Silva (2007) who argued colorblindness allows racism to fester continually in US society because it is not confronted. What should possibly also be addressed in studies of colorblindness is the role of Whiteness in its perpetuation.

\section{Whiteness and Education}

Educational researchers have examined Whiteness for decades. Whiteness has been conceptualized as, "hegemonic racial structurings of social and material realities operating in the present moment that perpetuate racialized inequalities and injustices" (Jupp, Berry \& Lensmire, 2016, p. 1154). In the latter part of the twentieth century, White scholars began to examine their own identities by questioning how Whiteness affected experiences for minoritized populations. For example, Bennett (2012) has shown McIntosh's (1990) work catalyzed a shift in the conceptualization of White privilege in the US from structurally designed to psychologically perpetuated. McIntosh presented instances that could be used by teacher educators to expose the privileges Whites received on a daily basis in the US. Lensmire et al., (2013), however, explained that McIntosh's (1990) model hampered the development of anti-racist practices because it became a stand-in for all anti-racist work. Moreover, these authors argued McIntosh's central thesis was incomplete because it was based on individual rather than structural levels of oppression. Similarly, Leonardo (2004) argued many White individuals do not acknowledge their role in the perpetuation of race-based privilege and systemic inequities within the US.

Other scholars (e.g., Bonilla-Silva, 2007; Fasching-Varner, 2013) described the ways Whiteness and socio-economic status can intertwine to provide experiences of stratification, neutralization of race, and bonding. Bonilla-Silva's (2007) work provides a lens to understand the ways many White individuals neutralize race based on "overcoming" marginalization. He explained,

They [working- and middle-class White individuals] look at their own lives and the lives of their parents and friends and see people who have worked very hard for everything they have achieved. The idea that they are privileged may seem very foreign to them. (p. 120)

Faschings-Varner's (2013) work provides a way to understand how White individuals coalesce structures of racialized privilege. As a White scholar, he explained White participants in his studies often felt they could speak candidly to him about race in ways they might have felt 
uncomfortable doing so with people of color. He developed the concept of White racial bonding to describe this occurrence. Scholars have tapped into White racial bonding in their work with White preservice teachers in discussions of race, racism and oppression.

Marx (2004) described the ways Whiteness undermined the intentions of White preservice teachers who claimed to abhor racism while tutoring youth from Mexican backgrounds. By developing trust with her participants, Marx was able to share interview transcripts to show how these tutors were simultaneously perpetuating deficit perspectives regarding their tutees while claiming to be anti-racist. While her study did not begin as an intervention, Marx felt it necessary to confront her participants about their deficit views based on the fact that each would be working (and was working) with marginalized students as classroom teachers in the future. Marx concluded that there were no easy solutions to racism because, "Whites cannot immediately stop being racist, nor can they/we suddenly reject our privileges" (p. 40). Other scholars have also discussed ways to engage White teachers in racial consciousness.

Yoon (2012) followed a group of White teachers at an elementary school within an urban context who hoped to support one another to, "raise awareness and develop cultural competence among school staff' (p. 597). She found many paradoxical outcomes in the group, whose members' efforts she termed as "Whiteness-at-work". One paradox was related to the choice of the phrase "cultural competence" in the group's goals. She explained this phrase was chosen because it was "race neutral." Yoon described this as a safety tactic designed with White people's comfort in mind. Moreover, she explained the inherent paradox in the teachers' goal of hoping to avoid conflict with one another by, "calling out colleagues without seeming like they were challenging each other (p. 598, emphasis on original). Yoon concluded these paradoxes maintained silence in conversations that were ironically meant to uncover problematic outcomes of racialization in the school.

The majority of the empirical work described above dealing with engaging White preservice and inservice teachers in racial conscious work was completed with individuals who might be considered "allies" in racial justice; that is, they believed in a multicultural sort of teaching. Where I hope to add to this substantial scholarship is by providing empirical data about how a teacher who does not consider herself an adherent of multiculturalism might engage in similar reflections on race, and the effects of her colorblind ideology on her teaching practice. 
Milner (2013) argued educational researchers must understand the contexts where they work to develop a clearer understanding of outcomes observed. In the following sections, I first provide the conceptual frameworks that guided my analysis. Both were used in an effort to abide by Milner's recommendation to deeply understand how context affects outcomes in relation to connections between student support and colorblindness. Next, I present the results from interviews with Ruth and observations completed in her classroom. I then discuss my interpretations of results and conclude with implications for future research undertaken to make connections between teacher praxis and practice.

\section{Conceptual Frameworks}

I was guided by elements of two conceptual frameworks, cultural-historical activity theory (CHAT) and critical whiteness studies (CWS), in my dialogues with Ruth and my analysis in answering the following research question:

- How does a White female teacher who adheres to a colorblind ideology interact with her students in the context of a rural school in the Mid-Atlantic United States?

I used specific elements of CHAT to examine how Ruth's school environment and present perceptions of race may have affected her interactions with students.

CHAT theorists are guided by three principles: (1) historicity; (2) understanding the entire context as the unit of analysis; and (3) contradictions and disruptions lead to growth (Engeström, Miettinen \& Punamäki, 1999). While I remained conscious of the first two principles, my analysis and data generation techniques were specifically guided by the second: understanding the entire context as the unit of analysis.

Engeström (1994) explained a conceptual model of CHAT is, “. . . particularly useful when one wants to make sense of systemic factors behind seemingly individual and accidental disturbances, deviations and innovations occurring in the daily practice of workplaces" (p. 46). Within CHAT, the guiding principles are used by researchers to uncover ways in which knowledge is transferred within specific contexts to develop applicable solutions to contextuallydependent problems. For the purposes of this study, I did not employ CHAT in an effort to develop any sort of intervention. Rather, I used the principle of understanding the entire context to guide my analysis and data generation. Context here is defined by experience. 
Drawing from Cole (1996), Engeström (2009) explained there is an alternative way to understand context. The term is rooted in the Latin word "contexere," which means "to weave together" (p. 23). Roth and Jornet (2017) provided the metaphor of a rope to more deeply understand this conceptualization. While a rope may seem at first glance to be a solid object, in actuality it is made up of smaller strands which are made up of smaller fibers. All of these elements weave together to make the rope. Conceptualizing context in this way through the second CHAT principle allowed me to engage in a sort of "nested" reflection to understand how students and teachers in the classroom I observed were affected by each other and components of the larger school, district, and community. I understood each component to presuppose the last.

Utilizing this CHAT principle alone, however, lacked an element of power that I hoped to address by analyzing how Ruth's colorblindness influenced her interactions with students in the context of HBE. Therefore, I embedded CWS within CHAT to place emphasis on the ways Whiteness contributed to the racial power dynamics within Ruth's classroom, school and community. I adhered to Jupp, Berry and Lensmire's (2016) definition of Whiteness presented above described as, "hegemonic racial structurings of social and material realities operating in the present moment that perpetuate racialized inequalities and injustices" (p. 1154). As such, my goal was to understand how Ruth's colorblindness was a product of her context, and the possible influence such adherence had on her decisions and actions related to her teaching practices such as pedagogy, academic supports, instruction, and relationships with students.

\section{Methods}

\section{Participant Selection}

In the first year of the study (2015-16), I selected individuals from a university's participant pool to take part in interviews with me regarding perceptions of racial privilege and systemic inequities. Instructors at the school of education where the first year of this study took place use the pool to list research opportunities for undergraduates. Each student must accrue a certain number of laboratory research credits to meet graduation requirements. Students utilized the pool to access the Quick Discrimination Index (QDI) (Ponterotto et al., 1995), and received one hour of laboratory credit upon completion.

Over 100 students initially took the survey. I contacted thirty prospective participants based on their race (White) and academic year in the teacher education program. Because of my 
goal to design a longitudinal study in an effort build a more meaningful working relationship with my participants, I purposively chose students in the second-to-last or final year of their program. I planned to interview them as preservice teachers, and then observe their practices in the first year of their inservice experiences. Considering Fasching-Varner's (2013) concept of White racial bonding, I hoped this two-year period would allow us to develop relationships for participants to feel comfortable sharing with me their personal views on race, oppression and teaching. Eight students were selected based on these criteria (6 White females, 2 White males).

At the end of the first year based on the geographical locations that the participants planned on interviewing for jobs, I chose four of the White female preservice teachers to observe in their classrooms during the next school year (2016-2017). While I planned on interviewing all participants throughout the study, I also hoped to observe them in their classrooms to discuss possible contradictions between interview and observations data. I hoped this would help me understand how the participants' perceptions of race might influence their actual interactions with students. Because of logistical issues related to distance for observations, I asked two of the four participants to continue the research process with me. Both agreed. I generated data with both participants, however, for the purposes of this article I will present data on only one: Ruth Austen.

Participant. Ruth self-identified as a White, heterosexual, Christian, cis-gendered, ablebodied female. She was raised in a small rural town and described herself as deeply committed to her Christian faith. She attended a five-year teacher education program in the Mid-Atlantic US from which she graduated with a Bachelor's degree (BA) in Religious Studies (primary concentration in Christianity and secondary in Judaism) and a Masters of Teaching (MAT) with an emphasis on early childhood education. At the time of our work together, she was in her early twenties.

Researcher Positionality. While we may share experiences based on our White identites, experiencing life as a White male and member of the Jewish faith provides me with a different gendered and religious experience than Ruth. For instance, I have been able to experience how my White identity can be marginalized when individuals find out I am Jewish. When I wear a kippah, also known as a yarmulke, my non-Jewish colleagues often ask me what my "little hat" is. This form of microaggression (Sue et al., 2007) reminds me of my place as a religious "other." 
The difference in this sort of marginalization when compared to that people of color or women face is I can take off my kippah and remain perceived as a "normal" White male (i.e., Christian). Moreover, as a male, I experience many forms of gendered privilege that Ruth may not. For instance, Ruth described her parents' advice of confirming any individual who might pull her over in a traffic stop was a police officer. She explained, "You don't unlock the door. You roll down the window to let them talk to you to verify that they're cops first and to not give anything until they tell you to (Interview 12, 5/13/2017). Worries for her wellbeing also manifested in her parents' habit of having Ruth check in with them on a daily basis. Based in part on being a male, I never experienced this sort of relationship with my parents. Because of differential experiences such as these, I contend we are all products of larger structures and systemic forces that contribute to our perceptions of reality and in turn influence our actions.

\section{Community Context}

Sites. Drawing from CHAT, understanding the contexts of each space where Ruth and I interacted became integral to understanding how our interactions might have influenced her perception of how to support her students. I conducted first year interviews in an office within a university's school of education. During the second year of the study, two locations served as the primary settings for our interactions: Ruth's classroom at Hay Bale Elementary (HBE) and a local coffee shop.

The coffee shop was located in the same community as HBE. According to the 2010 census, the community surrounding HBE is almost completely racially homogenous. Over 93.27\% of the population was recorded as White, with Black (3.76\%) and Two or More races $(1.52 \%)$ making up the larger minoritized groups. Households in the area reported a median income of $\$ 50,547$. As will be described below, Ruth's perception of the poverty students faced surrounding the school and personal experience growing up in similar conditions played a significant role in the development of her perception of equity in her classroom.

HBE is located in a rural area and shares a plot of land with the only middle and high schools for the county. The school's demographics were reported as, $85.3 \%$ White; 5.1\% Two or more races; 4.5\% Hispanic; 3.7\% Black; 3.4\%; 1.5\% Asian; 0\% Hawaiian Native/Pacific Islander; 0\% American Indian/Alaska Native. Nineteen students were enrolled in the third-grade class I observed. Ruth provided the following demographics of students in her classroom based on her own observations rather than the school's documentation: one Black female; one Biracial 
male; two Hispanic males (one Mexican the other "Unknown"); one Chinese male; nine White females; five White males.

\section{Data Generation}

With institutional review board (IRB) approval, I generated data over a two-year period (2015-2017). Data included classroom observations, interviews, reflection journals and a student focus group. For the purpose of this article, I only present data related to the interviews and observations.

Traditional Interviews. As recommended by Lofland, Snow, Anderson and Lofland (2006), first year interviews were designed to build rapport and create a comfortable and respectful working environment with Ruth. To do so, I tried to explain to Ruth throughout the interview process that it was not my goal to "judge" her answers, but rather understand her interpretations of the topics. I interviewed her four times for approximately 30-45 minutes over the academic year (2015-2016). Interviews were both open-ended and semi-structured. Topics of each consecutive interview were: (1) participant background (i.e., where she grew up, racial and ethnic dynamics of neighborhoods and schools, family life); (2) discussion of the concept of knowledge in relation to teaching; (3) beliefs about systemic inequities and White privilege; (4) discussion of how topics from the third interview may affect interactions with future students.

Dialogic Interviews. Second year interviews shifted to a dialogic format. I worked to create an environment where both Ruth and I were seen as "experts" in our specific fields (i.e., researcher with theory and teacher in relation to practical application). All dialogic interviews (ten in all) lasted approximately one hour and took place the week following a classroom observation. We met in a local coffee shop because I hoped meeting in a location outside of Ruth's school would provide a more comfortable place for us to engage in conversations of race, power, and oppression without colleagues or students possibly interrupting. In our early dialogues, Ruth and I established "loose rules of engagement." Specifically, we agreed to listen and respect each other's perspectives, not interrupt when the other was talking, and try not to judge one another based on our views. Dialogues often were wide-ranging, with topics related to her teaching, families and other aspects of our lives ${ }^{1}$.

\footnotetext{
${ }^{1}$ For a detailed discussion regarding these dialogues and our relationship in general, please see Bennett (2019).
} 
Observations. I considered myself a participant observer in that not only did I observe Ruth and her students, but I also interacted with them in the classroom. For instance, I would ask students about their days, what they were working on, or talk about anything they might ask me related to our work. On my first visit, I made my intentions of observing Ruth's interactions with them known to the class. I explained to the students that I was not there to observe them in particular, but rather Ruth's teaching and interactions with everyone. To apply this intention, I

placed the majority of my gaze on Ruth while taking note of student reactions to her supports. In total, I observed Ruth ten times for approximately 60 minutes every-other-week throughout the school year (2016-2017).

\section{Data Analysis}

Erickson (1985) and Corbin and Strauss (2014) explained key linkages should be searched for throughout analysis to understand possible patterns. To find these linkages related to our research question, I analyzed data by generating and testing assertions (Erickson, 1985). These were verified through repeated reviewing of field notes, write-ups, analytic memos, and interview transcripts. Through this process, I analyzed data through the technique of analytic induction $(\mathrm{AI})$.

AI is a strategy that allows researchers to develop explanations of interactional processes through which individuals develop distinct forms of social action (Smelser \& Bates, 200, pp. 23). Further, "initial cases are inspected to locate common factors and provisional explanations. As new cases are examined and initial hypotheses are contradicted, the explanation is reworked" (p. 1). This iterative process allowed me to test initial hypotheses based on the examination of new data (Smelser \& Baltes, 2001) through a search for disconfirming evidence. To develop these hypotheses, I used a process of memoing.

Analytic Memos. Memos were developed by "pulling out" key linkages I found between interview and observation data. Specifically, I used early memos to address possible patterns seen in the interactions between Ruth and her students collected in field notes. I shared the memos with Ruth during dialogic interviews to discuss her interpretation of the interactions observed. Then, I would review Ruth's answers in the transcripts from our dialogues and connect them back to the observation data. Analyzing data recorded in these memos allowed me to determine if and how Ruth's and my own thinking about equity-based teaching strategies shifted throughout dialogic interviews, and how this might also influence her interactions with 
students. For instance, after reviewing field notes, I would create a memo of patterns seen in the observation such as specific supports given to certain students or common interactions I felt were meaningful in some way. I would then take these memos to Ruth and ask her to explain her reasoning behind each. Based on her response, I would generate assertions to be tested against future observational data. This resulted in a validated assertion, confirmed with Ruth, and presented at the end of the results section below.

Overall, I adhered to Cho and Trent's (2006) definition of validity in evaluating qualitative research to determine the validity of my study. These authors proposed a, "recursive, process-oriented view of validity" (p. 319). In their approach, validity in qualitative research moves away from being based on "specific criteria" and toward a process of recursive reflection ever-present in the research design and implementation (p. 327). Moreover, the authors realize the pragmatic nature of social-science research in that they do not relegate any validity methods (of which they label "transactional" or "transformational") as better or worse. They explained, ". .. we are proposing an inclusive discourse of validity in qualitative research by reflecting on what matters specific to the problem/research within our research purview" (p. 333). As such, in relation to this study I hoped to constantly reflect on my positionality as a White, Jewish, cisgendered, heterosexual, able-bodied male alongside Ruth's reflections on her own positionality in relation to that of her students.

\section{Results}

\section{Removing Race, Removing Ethnicity}

Throughout this section, I present data that shows how Ruth's goal of removing race from her purview when interacting with students meant she removed ethnic markers of students' identities as well. Markus (2008) explained the difference between these identity categories. Although the creation of both categories are social constructions, dominant groups often define how races are perceived whereas ethnicities are relational processes in which members have greater influence in defining characteristics. Language and dialect, therefore, can be considered ethnic rather than racial traits.

During first year interviews, Ruth expressed a desire to treat students as "individuals." She explained, “. . . I think it always has to be individual based . . . every person has their own learning style and their own interests (Interview 2, 11/9/2015). When describing how White 
privilege might affect students in her future classroom Ruth responded, "I don't think that would be a problem because I approach everything, or try to approach everything on an individual basis" (Interview 4, 3/20/2015).

During second-year dialogic interviews as an inservice teacher, Ruth explained her definition of individualism in a more nuanced way:

For school, I'm thinking it's more of how you interact with [students], and in life it's like what makes them an individual . . their heritage, home life, economic status, their particular interests, and the people who are home with them ... I think you have to take those things into consideration, but [in the classroom] I'm thinking more of like my interactions ... you can think about the things that go on at home, but it's more about my experience with them when I'm saying they're individuals. (Interview 14, Dialogic, $7 / 7 / 2017)$

These views also affected her perception of how she should interact with students, specifically, her students of color.

Ruth described not being so far on the "spectrum" of colorblindness that she did not want to "see" race, but explained, "I see it [race], and I want to protect them [her students] from the bad parts of it [their race] or the parts that would make them feel less." She continued by describing Joy, the only Black female in her class, “. . . in her case, she just so good at what she does [school work]. She's amazing. And I just don't want anything to get into her head and make her feel bad about herself" (Interview 11, Dialogic, 4/6/2017).

Ruth also described how she perceived Sean, a Chinese American student in her class. She explained:

It's not like I don't recognize [Sean] is Chinese, but I don't want that to be really affecting how I view him . . . I'm not looking at, OK he's Chinese . . It's, OK, he speaks another language at home, I don't really take into consideration that it's Chinese.

(Interview 11, Dialogic, 4/6/2017)

She continued,

I don't want him to then walk into a room and be like, 'Chinese male, Chinese male, I'm a Chinese male.' I think that's what I'm most nervous about. I don't want it to be like a, 'This is the only thing I am'. (Interview 11, Dialogic, 4/6/2017)

She then made the point that she wanted Sean to see himself as more than Chinese by arguing, 
"Well, wouldn't it be a bad thing if I just saw the world through me being a female" (Interview 11, Dialogic, 4/6/2017)?

In further hoping to mitigate the role race played in the lives of her students (and her own), Ruth described differences between her two Latin(x) students, Johnny and Peter. In our second-to-last dialogue, I provided a memo to show she often compared her two Latin(x) students during our conversations. I showed her an excerpt of a transcript from a previous interview where she described Johnny as being "snarky" and then compared him to Peter, saying, "You've met Peter, he's not like that" (Interview 8, Dialogic, 2/10/2017). I asked her to explain why. She responded:

I think because in the beginning [of our dialogic interviews] when we were talking about them, we were talking about how the two Hispanic kids in class were so different. Which made me think that you can't just base it off, I didn't want to group them based on their race. (Interview 13, Dialogic, 6/6/2017)

In the earlier dialogues Ruth referenced, we were discussing the concept of "within-group differences" as described by Deutsch and Williams (2016). It was my goal to discuss with Ruth the possibility that even though Johnny and Peter might both be "Hispanic" in her eyes, they still likely had different experiences based on their race and ethnicity. Rather than acknowledge how being racialized may affect individuals from similar racial groups differently, my explanation seemed to further bolster Ruth's belief that factors other than race caused the different outcomes seen between the two students.

After one of our first dialogic interviews at the coffee shop, I sent Ruth Cohen and Garcia's (2008) article entitled Identity, Belonging and Achievement. My goal was to have Ruth reflect on and then talk about the article with me in relation to her perception of the needs of her students. In the article, the authors provided justification and strategies for teachers to acknowledge the race and ethnicity of their students to mitigate the effects of stereotype threat (Steele, 2010). We discussed her interpretations during our eleventh interview.

Ruth described that after reading the article, she reviewed her state's teaching standards in Social Studies. Upon review, she became conscious that specific people of color were only specifically referenced three times. She explained, "The current [standards], literally the only Black people [students] have to know about are Martin Luther King Jr., Rosa Parks, and Thurgood Marshall." She continued by explaining her perception that this "reinforced" the idea 
to her students of color that, "the only time that [race] is significant is when you're fighting for Civil Rights." This in turn affected how she felt her students of color might identify with their race. She described her belief that relegating experiences of people of color to the Civil Rights era was teaching her students of color that, "their race is the only thing that they're going to be able to do anything [with]...like, 'this is where [the student] could be special.' She explained this put a limitation on these students (Interview 11, Dialogic, 4/6/2017). She applied this perception to how she interpreted the needs of her students of color in her classroom at HBE. Using the entire context as unit of analysis, administrative regulations and unspoken norms in the school and community also seemed to affect Ruth's perception of her students, and how she believed she could support them.

\section{How Context Influenced Support}

At the beginning of the school year, Ruth reached out to all of her students' parents to introduce herself and set up a line of communication. She explained it was difficult to contact Sean's parents, the Chinese American student mentioned above. When I asked Ruth how she tried to contact them, she shared that front office staff told her she would not be able to reach them. They claimed that even if she was, it would not matter because the parents did not speak English (Interview 13, Dialogic, 6/6/2017).

After hearing this, I asked Ruth if she would be willing to meet Sean's parents at their home. She described his parents being extremely busy because they ran a local restaurant. Moreover, having grown up in a similar community to that of HBE, she believed parents would find a teacher coming to their home unannounced invasive. In such a rural environment, Ruth explained, "you make sure the persons know you're coming. You're not gonna show up randomly on some person's doorstep" (Interview 13, Dialogic, 6/6/2017). Still, she hoped to support Sean in her classroom based on her definition of equity.

Ruth described Sean as "hands down" her favorite student. When I asked why, she explained, "Because he does everything you say. And he does it quietly. And he does it to the best of his ability ... And like you just don't even really know he's there half the time" (Interview 13, Dialogic, 6/6/2017). In response, I asked Ruth if she was familiar with the "model minority" stereotype (Lee, 2015). I explained, "A lot of literature, a lot of stereotypes of Asian students, Chinese-Americans mostly, say that they are normally really quiet. They're not behavioral problems. And so, teachers don't really see they might be having problems" 
(Interview 13, Dialogic, 6/6/2017). She replied this may have been "part of" the reason why she was not aware of Sean's academic difficulties, but she felt more blame for her lack of acknowledgement should be placed on test scores given to her by Sean's previous teachers at the beginning of the year that showed he was "on grade-level" in reading comprehension.

In our eleventh interview (dialogic), I asked Ruth about infusing Banks' (2008) transformative approach of multicultural education in her curriculum. In this model, teachers support their students in taking on the perspectives of marginalized groups through such activities as reading, acting out specific experiences, or writing. Again, norms and rules within HBE seemed to affect her perceptions about developing a more culturally diverse curriculum. She stated, "Where it's hard is because it's not really even their [the reading specialist's] fault because they're getting things to support the [state] standards" (Interview 11, Dialogic, $3 / 28 / 2017$ ). She continued by describing that the "big concern" of administrators and others who selected the reading curriculum was getting students to pass state standardized reading tests, of which the school average was below passing in previous years. Therefore, she explained her perception that infusion of multiple perspectives would take "second priority" when the administration planned how to address failing reading scores.

Instructional Practices. Based on her perception that race or ethnicity did not affect a student's experience and that other factors played a bigger role, I observed Ruth to interact with all her students in similar ways. For example, Ruth created working groups in each content area (i.e., Math, Reading, Science, etc.) based on her students' achievement on benchmark assessments. While teaching these content areas, Ruth instructed each group to move around the classroom to different stations and complete activities together. This approach allowed students to work without teacher supports, however, one station was always with Ruth at a kidney shaped table. Here, I observed Ruth providing different supports to students based on her perception of their needs.

For instance, while reviewing prefixes and suffixes, Ruth wrote a sentence including a word without its prefix or suffix on a dry erase board and asked students to fill in its proper form (e.g., I love walk_ the dog). While working with each group, she spoke with all students at the same time. If she noticed a student was off-task or not participating, she stopped to ask that student to answer a question while individually helping them sound out the word. Ruth provided these supports for all her students. As addressed in the discussion/implications section below, 
this sort of differentiated instruction was influenced by her adherence to colorblindness and tantamount to her definition of equity.

Definition of Equity. Ruth's perception of individuality was part of her adherence to colorblindness and also contributed to her definition of equitable practice. As seen in the examples above, she did not associate acknowledging a student's race or ethnicity as being a part of creating equitable practice. Rather, she hoped to mitigate what she perceived to be the negative effects of her students identifying racially. When asked to define the concept of equitable teaching she replied:

My hierarchy is as follows: the basic needs of my students are met (i.e. like the student who needed to take naps and have snacks because they didn't have food at home), then emotional needs (i.e. the student who needed a special lunch with me or the student that needed to hold my hand to feel secure in the hallway). I don't feel like in my school [students'] emotional needs were directly related to their cultural identity or awareness (Personal Email Communication, 8/9/2017).

CWS allowed me to place an emphasis on Ruth's normalization of racialized experiences within the context of HBE during dialogic interviews. Ruth had the perception that her minoritized students were not adversely affected by "their cultural identity" in her classroom. Because of this, she found it hard to believe in, "fixing something that was not broken." She explained, It's hard until you experience a kid that's failing and having that issue of not having friends or seeing them be made fun of, until you're kind of in that situation . . . as it is right now, it's like, why try to fix something that doesn't seem like it's broken in my class (Interview 11, Dialogic, 4/6/2017)?

Such a perspective seemed to be made without speaking to any of her students of color about their feelings in relation to marginalization, and substantiates the work of the social psychology and other scholars presented above in that Ruth's colorblindness could create "blind spots" related to the marginalizing effects of racialization on her students of color.

Analysis of these data using CHAT and CWS through the search for disconfirming evidence and key linkages to validate observed patterns led to the generation of the following assertion $^{2}$ :

The context of Hay Bale Elementary bolstered Ruth's belief that a student's racial or

\footnotetext{
2 This assertion was shared and confirmed with Ruth.
} 
cultural identity did not contribute to their overall experience at the school. Therefore, she did not equate the development of equity-based practices with a student's race or ethnicity. Rather, she sought to support students based on her perspective of their individual academic and personal needs.

\section{Discussion/Implications}

The data presented above paint a picture of the ways a first-year White female teacher perceived the role of race within a specific school context. Often, Ruth was grappling with how to address race in her classroom and life in general. This in turn influenced her praxis in relation to equity, and therefore her practice related to ways she sought to support her students.

Using the entire context as unit of analysis, the community surrounding HBE contributed to her perception of equity and bolstered her adherence to colorblindness. The overwhelming White English-speaking majority surrounding HBE and the school itself provided Ruth and the office staff members the privilege of not having to take on another person's perspective when interacting with them, but rather assume parents should conform to their ways of doing. For instance, instead of considering different ways to contact Sean's parents, Ruth was permitted to forget about it. Such a result showed the ways Whiteness was normalized to marginalize certain communities both inside and outside HBE.

My analysis not only revealed how Ruth's adherence to colorblindness neutralized the effects of race in all aspects of her life, but also showed the intrinsic fallacy of the ideology. In claiming not to, "judge a person based on their race," Ruth was simultaneously explaining she had a perception of how races were stereotypically judged. Her comment that she was not, "so far on the spectrum" of colorblindness that she did not actually "see" race, but rather wanted to "protect her students from the bad aspects of it" was based on her judgement that race was a barrier to a student's wellbeing. Such a judgment was steeped in deficit thinking (Gorski, 2011). Moreover, it was clear that Ruth was indeed judging her student's race in that she did not apply this rationale to her White students. White teachers should consider why they feel students of color may need to be "protected" from their race. Does this in turn ironically create an environment where teachers feel that students need to be "protected" by placing negative connotations onto race? Rather, why not consider race (and other forms of marginalized 
identities) an asset for students? Race could be considered as providing everyone with a unique lens that contributes to both a person's daily experiences and perceptions of self-worth.

Ruth's hope to "protect" her students from the negative connotations of race also showed the ways Whiteness can normalize specific experiences within a classroom. As scholars (e.g., Matias, 2016) have shown, Ruth's goals of mitigating the role of race in her classroom perpetuated a standard experience based on the ways her White students (and she) experienced her classroom. How this specifically applied to her classroom in the context of HBE can be seen in Ruth's reaction to the Cohen and Garcia (2008) article.

Rather than interpret the article to justify the use of acknowledging race and ethnicity to inspire students in her class, her application of the article's tenets to the state standards revealed she believed race to be a limiting factor in the lives of her students of color. This resulted in instructional practices and interactions with students that mitigated the role of racialization as a possible reason for students lack of success or engagement in class. Moreover, it allowed her to not critique the overall practices in the school related to the development of a multicultural reading curriculum. Teachers should consider the fact that state-tests usually assess skills (e.g., reading comprehension). Therefore, the skills needed to pass these tests could be addressed using a variety of curricula content, including that which provides students transformative experiences related to taking on the perspectives of marginalized groups.

Ruth's adherence to colorblindness and perception of individuality also ironically affected her ability to acknowledge certain aspects of a student's individuality at HBE such as the racial, ethnic and cultural intersections of their identity. This was particularly troubling for her bilingual students in a variety of ways. The demographic information Ruth provided about her students revealed the ways her deficit judgements toward race affected her interactions with her bilingual students. Ruth listed Johnny’s ethnicity as "Unknown." It did not matter if Johnny was Mexican, Guatemalan, or Peruvian. Rather, to Ruth he was "Hispanic," and she compared his experiences to those of Peter even though they may have completely different ethnic backgrounds. Her solution of de-emphasizing the role race may play in Johnny’s life was a missed opportunity to understand possible reasons why he seemed "snarky" in her class. Based on Cohen and Garcia's (2008) work, Johnny might not feel comfortable in Ruth's classroom based on a lack of acknowledgment of his experience as a racialized person. 
Based in part on her colorblindness, Sean, Johnny, and Peter were considered the same in Ruth's eyes. This ironically resulted in similar supports being given to each when Ruth sought to differentiate her instruction. Ruth's comment during our second interview that, “. . . every person has their own learning style and their own interests, so I think everything has to [be individually based]," is considered by many educators to be good teaching practice (Tomlinson, 2008) and Ruth did this very well. When a teacher fails to acknowledge how race plays a central role in a student's experience, however, any sort of "individualized teaching" strategies fall short of being truly individualized.

An example of this can be seen in how Ruth supported her bilingual students. She developed instructional supports for the fact that English was not their native language. It did not matter that Johnny and Peter's ethnic identities may have differentially influenced their experiences in her room and within HBE when compared to Sean or each other. To her, both her Latin(x) students spoke a native language other than English and therefore, like Sean, they all required the same instructional supports. For instance, Chinese characters are vastly different than those used in the Spanish alphabet. Because of this basic difference, native Chinese speakers may experience learning to read in vastly different ways than their bilingual peers from Latin(x) backgrounds. Teachers should consider strategies such as Gay's (2010) culturally responsive teaching to obtain a deeper understanding of the ways bilingual students experience her/his/their specific classes and therefore increase the likelihood of designing useful instructional supports for all students.

Ruth's lack of acknowledgement toward how racialization affected her students also substantiated the work of Apfelbaum et. al (2010) who hypothesized that teachers who adhere to colorblindness might not be able to discern instances of discrimination in their classrooms. While I did not directly observe any racial discrimination occurring, Ruth's description that all her students of color were "popular" and "doing well" was somewhat misplaced. In particular, I often observed Johnny working on his own and not interacting much with other students in the class. Also, Sean's reading comprehension scores were consistently dropping throughout the year. Based in part on her colorblindness, Ruth placed the onus of such outcomes on factors other than the way these students were experiencing racialization. Even if this was not the cause, not considering it as a possibility limited Ruth's capacity to develop meaningful supports. Like a doctor trying to diagnose reasons for a disease, teachers should try to consider all possible 
reasons for students' experiencing both social and academic difficulties, and possibly discuss with the students themselves her/his/their feelings toward being comfortable in their classroom.

\section{Conclusions}

The data presented here shows how colorblindness can influence a teacher's conceptualization of equity, and therefore the application of equitable supports. In this study, such a conceptualization resulted in an incomplete understanding of the needs of bilingual students. More empirical work should be undertaken in which researchers seek to show how a teacher's praxis can contribute to her/his/their practice in relation to supporting marginalized students. In this study, understanding how community and school norms influenced the ways Ruth perceived she could interact with students and parents allowed me to gain a more complete picture of outcomes observed in her classroom related to instructional supports. Future educational researchers hoping to understand possible reasons for teacher interactions with students should consider the ways in which contextual norms influence both teaching praxis and practice.

While only one case, Ruth's experience shows the importance of understanding ways contexts are actually "weaving of experiences" and influenced by surrounding communities. Causes of marginalization are not be universal. To develop meaningful supports within multiple classrooms, contextual nuance must be considered using tools such as elements of CHAT. This could provide better opportunities to understand how marginalization occurs based on the specific makeup of certain schools and communities, leading to the amelioration of the perpetuation of specific types of inequity across multiple schools. 


\section{References}

Apfelbaum, E.P., Pauker K., Sommers, S.R., \& Ambady, N. (2010). In blind pursuit of racial equality?. Psychological Science, 21(11), 1587-1592.

Banks, J. (2008). Diversity, group identity, and citizenship education in a global age. Educational Researcher, 37(3), 129-139.

Barrett, K.H., \& George, W.H. (2005). Judicial colorblindness, race neutrality, and modern racism: How psychologists can help the courts understand race matters. In K. Barrett \& W. George (Eds.), Race, culture, psychology and law (pp. 31-46). Thousand Oaks: Sage.

Bennett, J.S. (2019). Fostering relational trust to engage white teachers and researchers on reflections of race, power, and oppression. Teaching and Teacher Education. 86, https://doi.org/10.1016/j.tate.2019.102896

Bennett, J.S. (2018). A privileged perspective: How a racially conscious White male teacher interacts with his students. Whiteness and Education, 3(1), 56-75.

Bennett, J.S. (2012). White privilege: A history of the concept. Thesis, Georgia State University. https://scholarworks.gsu.edu/history theses/54

Bonilla-Silva, E. (2007). Color-blind racism. In P. Rothenberg (Ed.), Race, class, and gender in the United States (pp. 131-138). New York: Worth Publishers.

Cohen, G. L., \& Garcia, J. (2008). Identity, belonging, and achievement: A model, interventions, implications. Current directions in psychological science, 17(6), 365-369.

Cole, M. (1996). Cultural psychology: A once and future discipline. Cambridge, MA: Harvard University Press.

Corbin, J. \& Strauss, A. (2014). Basics of qualitative research: Techniques and procedures for developing grounded theory. Thousand Oaks: Sage.

Edwards-Groves, C., Brennan Kemmis, R., Hardy, I., \& Ponte, P. (2010). Relational architectures: Recovering solidarity and agency as living practices in education. Pedagogy, Culture \& Society, 18(1), 43-54.

Engeström, Y., Miettinen, R., \& Punamäki, R.L. (1999). Perspectives on activity theory. New York: Cambridge University Press. 
Engeström, Y. (1994). Teachers as collaborative thinkers: Activity-theoretical study of an innovative teacher team. In I. Carlgren, G. Handal \& S. Vaage (Eds.). Teachers' minds and actions: Research on teachers' thinking and practice (pp. 43-61). London: Falmer Press.

Engeström, Y. (2009). From learning environments and implementation to activity systems and expansive learning. Actoi: An International Journal of Human Activity Theory, 2, 17-33.

Erickson, F. (1985). Qualitative methods in research on teaching. Occasional Paper No. 81. Washington, DC: National Institute of Education.

Fasching-Varner, K. J. (2013). " Uhh, You Know," Don't You?: White Racial Bonding in the Narrative of White Pre-Service Teachers. Educational Foundations, 27, 21-41.

Gay, G. (2010). Culturally responsive teaching: Theory, research, and practice. New York: Teachers College Press.

Gorski, P. C. (2011). Unlearning deficit ideology and the scornful gaze: Thoughts on authenticating the class discourse in education. Counterpoints, 402, 152-173.

Jupp, J.C., Berry, T.R., \& Lensmire, T.J. (2016). Second-wave white teacher identity studies: A review of white teacher identity literatures from 2004 through 2014. Review of educational research, 86(4), 1151-1191.

Lee, S. J. (2015). Unraveling the" model minority" stereotype: Listening to Asian American youth. New York: Teachers College Press.

Lensmire, T.J., McManimon, S., Tierney, J.D., Lee-Nichols ,M., Casey, Z., Lensmire, A. \& Davis, B. (2013). McIntosh as synecdoche: How teacher education's focus on white privilege undermines antiracism. Harvard Educational Review, 83(3). 410-431.

Leonardo, Z. (2004). The color of supremacy: Beyond the discourse of 'white privilege'. Educational Philosophy and Theory, 36(2). 137-152.

Lofland, J., Snow, D.A., Anderson, L.L., \& Lofland, L.H. (2006). Analyzing social settings: A guide to qualitative observation and analysis. Boston: Wadsworth/Thomas Learning.

Markus, H. R. (2008). Pride, prejudice, and ambivalence: toward a unified theory of race and ethnicity. American Psychologist, 63(8), 651.

Marx, S. (2004). Regarding whiteness: Exploring and intervening in the effects of white racism in teacher education. Equity \& Excellence in Education, 37(1), 31-43.

Matias, C.E. (2016). Feeling white: Whiteness, emotionality, and education. Boston: Sense. 
McIntosh, P. (1990). Unpacking the Invisible Knapsack. Independent School, Winter, 31-36.

Milner IV, H. R. (2010). Start where you are, but don't stay there. Cambridge: Harvard Education Press.

Milner IV, H. R. (2012). Rethinking achievement gap talk in urban education. Urban Education, $10.1177 / 0042085912470417$

Milner IV, H. R. (2013). Analyzing poverty, learning, and teaching through a critical race theory lens. Review of Research in Education, 37(1), 1-53.

Milner, IV, H. R., \& Laughter, J. C. (2015). But good intentions are not enough: Preparing teachers to center race and poverty. The Urban Review, 47(2), 341-363.

Ponterotto, J.G., Burkard, A., Rieger, B.P., Grieger, I., D'Onofri, A., Dubuisson, A., Heenehan, M., Millstein, B., Parisi, M., Rath, J.F. and Sax, G. (1995). Quick Discrimination Index [Database record]. Retrieved from PsycTESTS. doi: http://dx.doi.org/10.1037/t03560$\underline{000}$

Rosenthal, L. \& Levy, S.R. (2010). The colorblind, multicultural, and polycultural ideological approaches to improving intergroup attitudes and relations. Social Issues and Policy Review, 4(1). 215-246.

Roth, W. M., \& Jornet, A. (2017). Theorizing with/out "Mediators". Integrative Psychological and Behavioral Science, 1-21.

Ryan, C.S., Hunt, J.S., Weible, J.A., Peterson, C.R., \& Casas, J.F. (2007). Multicultural and colorblind ideology, stereotypes, and ethnocentrism among Black and White Americans. Group Processes \& Intergroup Relations, 10(4). 617-637.

Smelser, N.J. \& Baltes, P.B. (2001). International encyclopedia of the social \& behavioral sciences. Amsterdam: Elsevier.

Steele, C. M. (2011). Whistling Vivaldi: And other clues to how stereotypes affect us (issues of our time). New York: WW Norton \& Company.

Sue, D.W., Capodilupo, C.M., Torino, G.C., Bucceri, J.M., Holder. A., Nadal, K.L., \& Esquilin, M. (2007). Racial microaggressions in everyday life: implications for clinical practice. American psychologist, 62(4). 271.

Tomlinson, C.A. (2008). Goals of Differentiation. Educational Leadership. 66(3), 26-30. 
Williams, J. L., \& Deutsch, N. L. (2016). Beyond between-group differences: Considering race, ethnicity, and culture in research on positive youth development programs. Applied Developmental Science, 20(3), 203-213. 